\title{
Stable isotope characteristics of eclogites from the ultra-high-pressure metamorphic terrain, east-central China
}

\author{
Tzen-Fu Yui ${ }^{a,}{ }^{*}$, Douglas Rumble III ${ }^{b}$, Chen-Hong Chen ${ }^{a}$, Ching-Hua Lo ${ }^{c}$ \\ a Institute of Earth Sciences, Academia Sinica, P.O. Box 1-55, Nankang, Taipei, Taiwan, R.O.C. \\ ${ }^{b}$ Geophysical Laboratory, Carnegie Institution of Washington, 5251 Broad Branch Road NW, Washington, DC 20015-1305, USA \\ ' Department of Geology, National Taiwan University, Taipei, Taiwan, R.O.C.
}

Received 8 February 1996; accepted 24 October 1996

\begin{abstract}
A stable isotope study was made for the ultra-high-pressure (UHP) metamorphic rocks in the Dabie and Sulu terrains, east-central China. $\delta^{18} \mathrm{O}$ values of minerals in eclogites cover a wide range, from -4 to $+6 \%$. The $\mathrm{O}$-isotope fractionations between minerals (i.e. omphacite, phengite and/or amphibole) and garnet in eclogites are mostly not in isotopic equilibrium. The large range of $\mathrm{O}$-isotope composition of garnet may approximate the $\delta^{18} \mathrm{O}$ variations of eclogites during UHP metamorphism and must have been largely inherited from their pre-subduction basaltic precursors which might have interacted with meteoric waters under variable temperature conditions and water/rock ratios before UHP metamorphism. The $\mathrm{O}$-isotope disequilibrium between minerals and garnet in eclogites was caused by retrograde hydration reactions. The fluids required for these hydration reactions must have low or even negative O-isotope compositions. It is postulated that such fluids were either originated from meteoric deep-infiltration or were derived from low- $\delta^{18} \mathrm{O}$ (para)gneisses.
\end{abstract}

Keywords: Stable isotope; Eclogite; Ultra-high-pressure metamorphism; China

\section{Introduction}

The discovery of coesite, coesite pseudomorphs and diamond as tiny inclusions in minerals in eclogite and other metamorphic rocks of supracrustal origin has profoundly changed common notions about the depth limits of metamorphic rocks now exposed at the Earth's surface (Chopin, 1984; Sobolev and Shatsky, 1990). The coesite/diamond-bearing rocks, therefore, define a new ultra-high-pressure (UHP) metamorphic facies. Extensive petrological and ex-

\footnotetext{
${ }^{*}$ Corresponding author.
}

perimental studies on these rocks have been carried out. The results show that the stabilities of UHP mineral assemblages require abnormally low geothermal gradients of $\sim 7^{\circ} \mathrm{C} / \mathrm{km}$, which can only be attained by the subduction of a cold oceanic crust with pelagic sediments or old, cold continental crust (e.g., Schreyer, 1988; Liou et al., 1994). The problems concerning the preservation and exhumation of these UHP metamorphic rocks, as well as the fluidrock interactions during UHP metamorphism and the following exhumation, however, are less understood and are yet to be resolved.

The Dabie and Sulu terrains in east-central China are generally considered the suture zones between 
the Sino-Korean and Yangtze cratons (Fig. 1). These two terrains contain the largest areal exposure of UHP metamorphic rocks known on Earth. The $P-T$ paths of these UHP metamorphic rocks have been studied in detail by various authors (e.g., Hirajima et al., 1990; Wang et al., 1990, 1992; Enami et al., 1993; Wang and Liou, 1993; Zhang et al., 1995). In general, most rocks contain a peak (i.e. UHP) and a retrograde (i.e. amphibolite/greenschist) metamorphic mineral assemblage. The retrograde processes involve both decompression and hydration reactions.
It has been suggested that the latter were most probably triggered by fluid infiltration during the exhumation of these UHP metamorphic terrains (Wang and Liou, 1991). Some preliminary stable isotope studies on these Chinese UHP rocks have been carried out by Xie (1993), Baker et al. (1994), Yui et al. (1994, 1995), J. Chen et al. (1995), and Zheng et al. (1995). Among them, Yui et al. (1995) showed that the eclogite and associated quartzite at Qinglongshan in the Sulu terrain exhibit $\delta^{18} \mathrm{O}$ values of around -10 to $-8 \%$, which are some of the

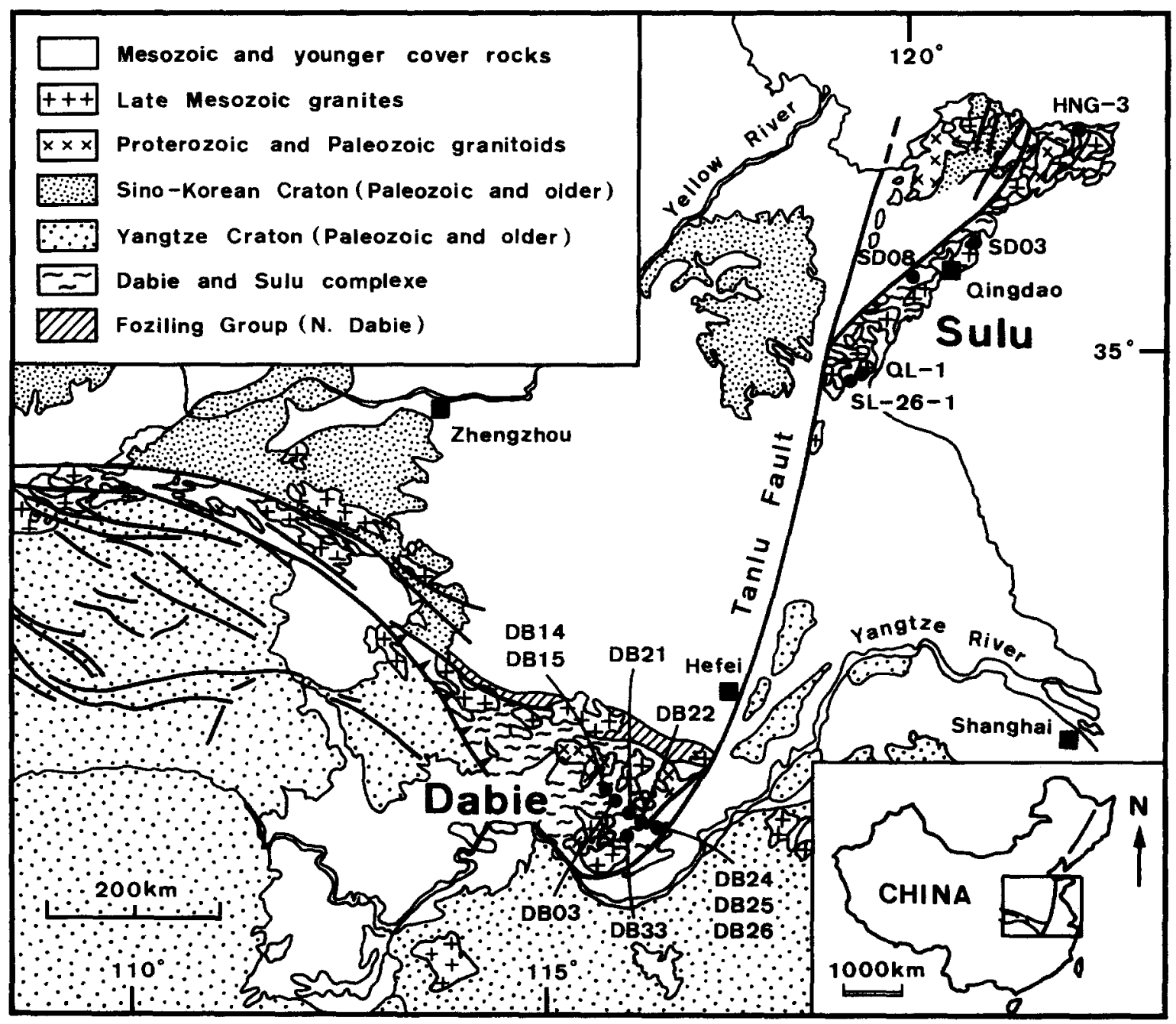

Fig. 1. Simplified geologic map of the Dabie and Sulu ultrahigh-pressure metamorphic terrains in east-central China (modified after Jahn et al., 1995) showing the localities of samples discussed in the present study. Different suffixes (i.e. A, B, C, ...) after each sample number in Tables 1-4 represent different samples collected from the same outcrop. 
most negative $\mathrm{O}$-isotope compositions ever reported for metamorphic rocks. The data clearly demonstrate that the UHP metamorphic rocks in east-central China must have experienced very distinct water-rock interactions during their lifetime. This paper shows that, based on the O-isotope compositions, the eclogites in the Dabie and Sulu terrains have interacted with some low- $\delta^{18} \mathrm{O}$ fluids both before and after the UHP metamorphism.

\section{General geology}

The Dabie and the Sulu UHP metamorphic terrains in east-central China are interpreted as having resulted from the collision of the Sino-Korean and Yangtze cratons during 240-200 Ma (Ames et al., 1993; $\mathrm{Li}$ et al., 1993, 1994). These two terrains were separated by the left-lateral Tanlu fault for a distance of at least $500 \mathrm{~km}$ (Fig. 1), probably during Cretaceous and/or Cenozoic time. The UHP metamorphic rocks in the two terrains mainly include eclogite, marble, (para)gneiss, amphibolite and ultramafics. The protoliths of the UHP rocks are believed to have formed in the Precambrian ( $\mathrm{Li}$ et al., 1993; Jahn et al., 1996). Inclusions of coesite and coesite pseudomorphs in zircon, garnet, omphacite, kyanite, epidote and zoisite are rare but widely distributed in both terrains (Okay et al., 1989; Wang et al., 1989; Yang and Smith, 1989; Hirajima et al., 1990; Wang and Liou, 1991; Xu et al., 1992; Zhang et al., 1995). Diamond inclusions, however, have only been reported in the Dabie terrain (Xu et al., 1992; Okay, 1993).

The metamorphic $P-T$ conditions for these UHP rocks have been extensively studied, and the results show spatial variations. The peak metamorphic $P-T$ conditions decrease from east to west in the Sulu terrain. To illustrate, $P>28 \mathrm{kbar}$ and $T=810$ $880^{\circ} \mathrm{C}$ in the east, whereas $P>26$ kbar and $T=$ $500-750^{\circ} \mathrm{C}$ in the west (e.g., Enami et al., 1993; Zhang et al., 1995). They also decrease from north to south in the Dabie terrain: $P>35 \mathrm{kbar}$ and $T=$ $750-850^{\circ} \mathrm{C}$ in the north compared with $P=20-25$ kbar and $T=580-650^{\circ} \mathrm{C}$ in the south (e.g., Wang et al., 1990, 1992; Okay, 1993; Wang and Liou, 1993). The peak metamorphic mineral assemblages are garnet, omphacite, phengite, epidote, quartz/coesite, kyanite, carbonates, rutile, ilmenite and glaucophane in eclogite (e.g., see Table 1); calcite/aragonite, dolomite, clinopyroxene, phengite, epidote, rutile and quartz/coesite in marble; and garnet, phengite, rutile, quartz/coesite in (para)gneiss. All these UHP metamorphic rocks show different degrees of amphibolite/greenschist-facies retrograde overprint. The timing of this retrograde metamorphism is consid-

Table 1

Estimated modal compositions and amount of symplectite in omphacite separates of eclogite samples

\begin{tabular}{|c|c|c|c|c|c|c|c|c|c|}
\hline & Garnet & Ornphacite & Phengite & Epidote & $\begin{array}{l}\text { Quartz/ } \\
\text { coesite }\end{array}$ & Rutile & Symplectite & $\begin{array}{l}\text { Late } \\
\text { amphibole }\end{array}$ & $\begin{array}{l}\text { Amount of symplectite } \\
\text { in omphacite separate } \\
\text { (wt\%) }\end{array}$ \\
\hline DB03-A & 65 & 25 & tr. & 1 & 3 & 3 & 2 & tr. & $<10$ \\
\hline DB03-C & 40 & 17 & 7 & 3 & 2 & tr. & 20 & 10 & 30 \\
\hline DB14-A & 45 & 30 & 5 & - & 3 & 1 & 10 & 5 & $<10$ \\
\hline DB21-D & 50 & 40 & tr. & - & - & 2 & 5 & 2 & $<10$ \\
\hline DB24-B & 50 & 15 & tr. & - & 18 & 3 & 10 & 3 & $<10$ \\
\hline DB25-B & 50 & 20 & 3 & tr. & tr. & 1 & 15 & 10 & 25 \\
\hline DB33 & 40 & 15 & 10 & tr. & 2 & 2 & 20 & 10 & 20 \\
\hline SD03-A4 & 45 & 15 & 5 & - & tr. & 2 & 25 & 8 & 35 \\
\hline SD03-A5 & 50 & 15 & 2 & 1 & tr. & 1 & 20 & 10 & 20 \\
\hline SD08-C & 45 & 30 & 5 & 3 & tr. & 1 & 10 & 5 & 15 \\
\hline SD08-D & 45 & 20 & 7 & 1 & tr. & 1 & 15 & 10 & - \\
\hline SL-26-1 ${ }^{b}$ & & & & & & & & & 10 \\
\hline
\end{tabular}

tr. $=$ trace

${ }^{a}$ Rough estimations were made based on the X-ray diffractograms of omphacite separates of each sample.

${ }^{b}$ Mineral separates of sample SL-26-1 were provided by J.G. Liou. Petrographic observations were not made for this sample. 
ered to be in the range of $200-180 \mathrm{Ma}$ (W. Chen et al., 1992; Lin et al., 1994; Hacker and Wang, 1995). The eclogite blocks enclosed within (para)gneiss or marble are generally amphibolitized in the peripheries. Amphibolite/eclogite interlayers in some outcrops also show gradational mineralogical changes, demonstrating that eclogite could well be the precursor rock of the amphibolite. The most obvious retrograde features in the eclogites include symplectite (i.e. intergrowths of Na-plagioclase, Ca-amphibole, Ca-pyroxene and epidote) after omphacite/garnet and the formation of retrograde amphiboles (Table 1). The minerals in marble were also replaced by pargasitic hornblende, epidote, diopside, plagioclase, phlogopite and tremolite. The (para)gneisses, however, are almost completely retrogressively metamorphosed. Peak metamorphic minerals are mainly present as inclusions in garnet. The retrograde amphibolite-facies mineral assemblage includes quartz, plagioclase, phengite, epidote, garnet, hornblende, $\mathrm{K}$ feldspar, biotite, titanite and opaques. Retrograde reaction textures are rare although phengite replaced by biotite and feldspars is not uncommon. The retrograde $P-T$ conditions were also suggested to show a decreasing trend from east to west: $P>9 \mathrm{kbar}$ and $T>680^{\circ} \mathrm{C}$ for the eastern Sulu terrain, $P<10 \mathrm{kbar}$ and $T<580^{\circ} \mathrm{C}$ for the western Sulu terrain, and $P=6 \mathrm{kbar}$ and $T=470-530^{\circ} \mathrm{C}$ for the Dabie terrain (Wang et al., 1990, 1992; Enami et al., 1993; Cong et al., 1995; Zhang et al., 1995).

\section{Sampling and analytical methods}

Samples in the present study include eclogite, marble and (para)gneiss. Eclogites and the enclosing (para)gneisses were collected from both the Dabie and Sulu UHP terrains, but marbles, mainly as blocks within (para)gneisses, were only collected from the Dabie terrain (Fig. 1).

Quartz, garnet, omphacite, amphibole, phengite and/or biotite were separated from eclogite and (para)gneiss samples for isotopic analyses using conventional separation techniques. While quartz, garnet, amphibole, phengite and biotite separates are relatively pure, omphacite separates from all eclogite samples invariably contain some symplectitic intergrowths and are, therefore, mixtures of peak and retrograde mineral phases. These omphacite separates were roughly divided into slightly retrograded (\#1) (i.e. containing < 15\% symplectite) and significantly retrograded (\#2) (i.e. containing 15-35\% symplectite) ones on the basis of petrographic observation and X-ray diffraction data (Table 1). Silicate minerals in marble samples were concentrated through acid digestion of the host marble. The resulting silicates as a whole, without further mineral separation, were isotopically analyzed.

Except for the marble silicates and (para)gneiss samples, oxygen was extracted from mineral separates following the method described by Sharp (1990, 1992) with the use of a stable isotope laser probe located at the Geophysical Laboratory. Silicates from marbles and (para)gneisses, however, were analyzed by the conventional $\mathrm{BrF}_{5}$ method (Clayton and Mayeda, 1963) at the Institute of Earth Sciences (IES). The precision of the analyses was generally better than $\pm 0.2 \%$. The isotopic reference material NBS-28 has a $\delta^{18} \mathrm{O}$ value of $+9.3 \%$ at the Geophysical Laboratory (Rumble and Hoering, 1994) and $+9.6 \%$ at the IES. To get internal consistency, the isotopic results from the IES were all normalized with NBS-28 equal to $+9.3 \%$.

Calcite and dolomite from marble samples were analyzed for their $\mathrm{C}$ - and $\mathrm{O}$-isotope compositions at the IES. The selective acid extraction method proposed by Al-Aasm et al. (1990) was employed when both calcite and dolomite coexisted.

Chemical compositions of phengite and amphiboles were also determined with a JEOL 8900 Super Probe at the IES.

\section{Results and discussion}

\subsection{Meteoric water-rock interaction before UHP metamorphism}

The O-isotope compositions of eclogites in the present study show two characteristics (Table 2). First, the $\delta^{18} \mathrm{O}$ values of the minerals cover a wide range. For example, the $\delta^{18} \mathrm{O}$ value ranges from -4.6 to $+6.0 \%$ for garnet, from -4.3 to $+5.7 \%$ o for omphacite and from -3.8 to $+3.7 \%$ for phengite, and the $\delta^{18} \mathrm{O}$ value of one amphibole is $+1.9 \%$. If the data by Xie (1993) [ $\delta^{18} \mathrm{O}$ (sample 6) $=-5.7 \%$ 
Table 2

Oxygen isotope composition of minerals in eclogites

\begin{tabular}{|c|c|c|c|c|c|}
\hline Sample & Mineral " & $\begin{array}{l}\delta^{18} \mathrm{O} \\
\text { (\%o vs. SMOW) }\end{array}$ & Sample & Mineral $^{a}$ & $\begin{array}{l}\delta^{18} \mathrm{O} \\
\text { (\%o vs. SMOW) }\end{array}$ \\
\hline DB03-A & $\begin{array}{l}\text { garnet } \\
\text { omphacite \#1 }\end{array}$ & $\begin{array}{l}+3.4 \\
+2.9\end{array}$ & SD03-A4 & $\begin{array}{l}\text { garnet } \\
\text { omphacite \#2 }\end{array}$ & $\begin{array}{l}+4.7 \\
+2.9\end{array}$ \\
\hline DB03-C & $\begin{array}{l}\text { phengite } \\
\text { garnet } \\
\text { omphacite \#2 }\end{array}$ & $\begin{array}{l}+3.7 \\
+3.3 \\
+2.8\end{array}$ & SD03-A5 & $\begin{array}{l}\text { garnet } \\
\text { omphacite } \# 2\end{array}$ & $\begin{array}{l}+4.8 \\
+3.4\end{array}$ \\
\hline DB14-A & $\begin{array}{l}\text { phengite } \\
\text { garnet }\end{array}$ & $\begin{array}{l}+1.1 \\
+0.7\end{array}$ & SD08-C & $\begin{array}{l}\text { garnet } \\
\text { omphacite \#2 }\end{array}$ & $\begin{array}{l}+2.7 \\
+2.1\end{array}$ \\
\hline & omphacite \#1 & +0.1 & SD08-D & $\begin{array}{l}\text { garnet } \\
\text { amphibole }\end{array}$ & $\begin{array}{l}+2.8 \\
+1.9\end{array}$ \\
\hline DB21-D & $\begin{array}{l}\text { garnet } \\
\text { omphacite \#1 }\end{array}$ & $\begin{array}{l}+4.6 \\
+3.6\end{array}$ & SL-26-1 & $\begin{array}{l}\text { phengite } \\
\text { garnet }\end{array}$ & $\begin{array}{l}+4.5 \\
+2.9\end{array}$ \\
\hline DB24-B & $\begin{array}{l}\text { garnet } \\
\text { omphacite \# } 1\end{array}$ & $\begin{array}{l}+6.0 \\
+5.7\end{array}$ & & omphacite \#1 & +2.3 \\
\hline DB25-B & $\begin{array}{l}\text { garnet } \\
\text { omphacite \#2 }\end{array}$ & $\begin{array}{l}+5.5 \\
+3.2\end{array}$ & & & \\
\hline DB33 & $\begin{array}{l}\text { phengite } \\
\text { garnet } \\
\text { omphacite \#2 }\end{array}$ & $\begin{array}{l}-3.8 \\
-4.6 \\
-4.3\end{array}$ & & & \\
\hline
\end{tabular}

a All omphacite separates actually contain different amounts of symplectite (intergrowths of Na-plagioclase, Ca-amphibole and/or Ca-pyroxene). Omphacite samples marked by ${ }^{\# 2}$ contains higher amount $(15-35 \%)$ of symplectite than those marked by ${ }^{\# 1}(<15 \%)$.

(amphibole)], Yui et al. (1995) $\left[\delta^{18} \mathrm{O}(\mathrm{QL}-1)=\right.$ $-9.0 \%$ (phengite), $-10.4 \%$ (garnet) and $-10.2 \% o$ (omphacite)], and Jahn et al. (1996) [ $\delta^{18} \mathrm{O}$ (HNG-3) $=+6.6 \%$ (garnet) and $+4.5 \%$ (amphibole) $]$ are considered, the O-isotope compositional range for the eclogites from the Dabie and Sulu terrains is even larger. Second, the isotopic fractionations between minerals clearly demonstrate that the minerals in most of the eclogite samples are not in isotopic equilibrium. To illustrate, $\Delta^{18} \mathrm{O}_{\text {(omphacite-garnet) }}=$ -2.3 to $+0.3 \% o, \quad \Delta^{18} \mathrm{O}_{\text {(amphibole-garnet) }}=-0.9 \%$, and $\Delta^{18} \mathrm{O}_{\text {(phengite-garnet) }}=+0.4$ to $+1.6 \%$ (Fig. 2). Based on available fractionation relations, the $\Delta^{18} \mathrm{O}$ values between amphibole/omphacite and garnet should be positive, and between phengite and garnet should be larger than $0.5-0.8 \%$ o under the temperature conditions of these UHP rocks (Javoy, 1977; Richter and Hoernes, 1988; Zheng, 1993a,b; Hoffbauer et al., 1994).

Compared with the published O-isotope compositions of eclogites outside China, which range from +1.5 to $+12.0 \%$ (Taylor and Coleman, 1968; Vo- gel and Garlick, 1970; Garlick et al., 1971; Desmons and O'Neil, 1978; Matthews and Schliestedt, 1984; Agrinier et al., 1985; MacGregor and Manton, 1986; Ongley et al., 1987; Schliestedt and Matthews, 1987; Nadeau et al., 1993; Jacob et al., 1994), some UHP eclogites in the Dabie and Sulu terrains evidently have distinctly lower $\delta^{18} \mathrm{O}$ values. The published $\delta^{18} \mathrm{O}$ values of eclogites can be most properly interpreted as having resulted from pre-subduction water-rock interactions, i.e. seawater-oceanic crust hydrothermal reactions, under different temperature conditions and variable water/rock ratios, with the presumption that the precursors of the eclogites are oceanic crust (Gregory and Taylor, 1986; MacGregor and Manton, 1986; Ongley et al., 1987). Such a scenario, however, cannot explain the negative $\delta^{18} \mathrm{O}$ values of eclogite sample DB33 in the present study, if the O-isotope composition of seawater has not deviated too much from that of the present-day ocean during geologic time (Muehlenbachs, 1986). Surface/meteoric water, the largest reservoir on Earth with negative $\mathrm{O}$-isotope compositions, must 
have been involved in the proposed genetic processes.

The O-isotope compositions of eclogites in the present study range from about -4 to $+6 \%$, a range which is lower than or at least close to the $\delta^{18} \mathrm{O}$ value of their basaltic precursors, presumably in the range of +6 to $+7 \%$ o (Taylor, 1968). As mentioned previously, the minerals in most of these eclogites are not in isotopic equilibrium. This has obviously been caused by retrograde reactions, such as the symplectitic replacement after omphacite and the formation of edenitic/pargasitic amphibole. It should be noted that although phengites in the present study are chemically homogeneous, for example with the Si content ranging from 3.5 to 3.6 atoms per structural formula unit, an isotopic disequilibrium between phengite and garnet in some samples is obvious (Fig. 2). The spread and lowering in the $\delta^{18} \mathrm{O}$ values of these eclogites, therefore, could be one of the retrograde results caused by the infiltration of external fluids.

If the $\delta^{18} \mathrm{O}$ values of eclogites in the present study were close to +6 to $+7 \%$ o before the exhumation processes and decreased to different degrees due to retrograde reactions with infiltrated fluids, the O-isotope fractionations between omphacite/phengite and garnet should have become smaller or even reversed with a decrease in the $\delta^{18} \mathrm{O}$ values of garnet (i.e. with an increase in the degree of retrograde reactions). This is in light of the fact that retrograde reactions may not have reached isotopic equilibrium and garnet is the most resistant to isotopic exchange during cooling among these minerals (e.g., Gregory and Criss, 1986). However, it is noted that the degree of isotope-fractionation reversal between omphacite/phengite/amphibole and garnet in the present study, especially for the more altered samples, generally decreases with a decrease in the $\delta{ }^{18} \mathrm{O}$ value of garnet in each sample (Fig. 2). This relation clearly demonstrates that although the O-isotope compositions of omphacite, phengite and amphibole could have been affected by retrograde reactions, such reactions could not have been the main reason for the O-isotope compositional variation of garnet. If the possibility of the presence of large amount of fluids during UHP metamorphism can be excluded (Liou and Zhang, 1995) and the prograde metamorphic effects generally do not lower the $\delta^{18} \mathrm{O}$

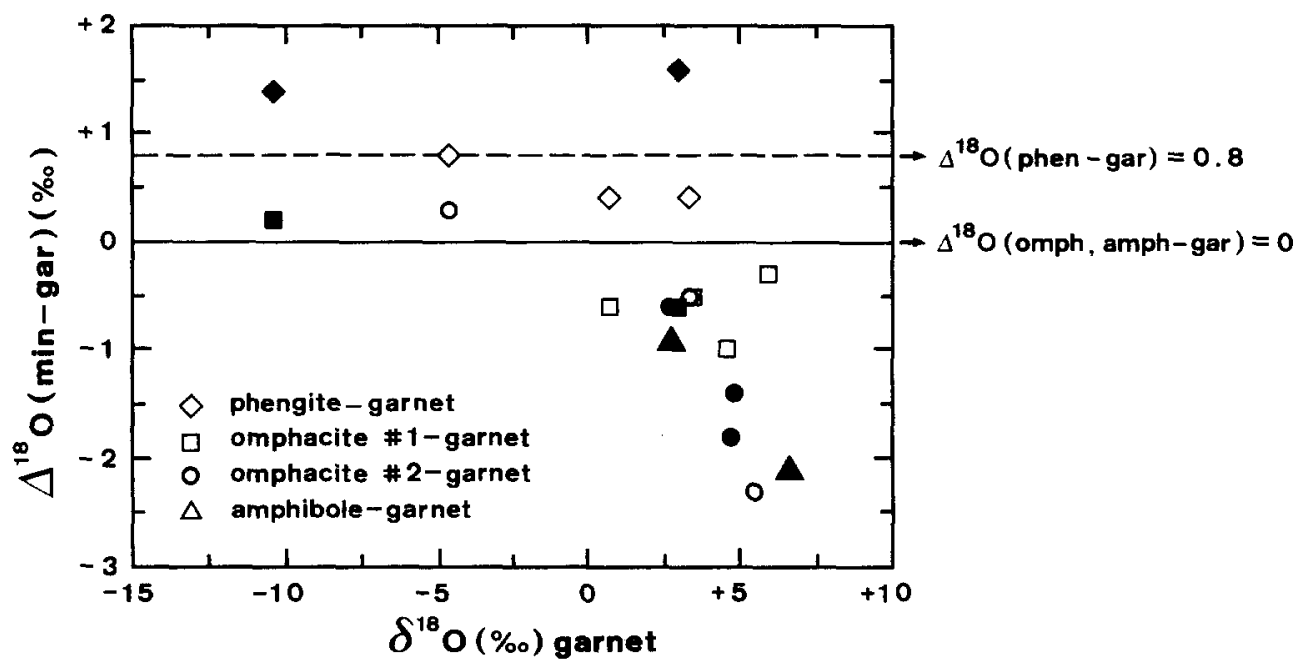

Fig. 2. O-isotope fractionations between phengite/omphacite/amphibole and garnet vs. $\delta^{18} \mathrm{O}$ values of garnet. Two reference lines marking the limit of non-reversed isotopic fractionation between phengite and garnet and between omphacite, amphibole and garnet, respectively, are also shown. See text for details. Open symbols are samples collected from the Dabie terrain, whereas closed symbols are samples from the Sulu terrain. Data for sample QL-1 and HNG-3 presented by Yui et al. (1995) and Jahn et al. (1996), respectively, are also included. Omphacite separate for QL-1 is only slightly retrograded (Yui et al., 1995) and therefore belongs to omphacite" 
value of a rock by more than 1-2\%o (Valley, 1986), the pre-subduction basaltic precursors of eclogites must therefore have been variable in their O-isotope composition to account for the spread in the $\delta^{18} \mathrm{O}$ values of garnet.

In the study of Qinglongshan eclogite in the Sulu terrain, Yui et al. (1995) showed that the minerals in eclogite are unusually low in oxygen isotopic compositions (i.e. around $-10 \%$ o) and are close to O-isotope equilibrium. They concluded that the anomalously low O-isotope composition was acquired under pre-subduction near surface conditions in a high-latitude meteoric water/hydrothermal system. Ultra-high-pressure metamorphism is not required to achieve these negative $\delta^{18} \mathrm{O}$ values. Support for this view is found in the Largs terrain, New Zealand, where $\delta^{18} \mathrm{O}$ values as low as $-13 \%$ in contact metamorphosed andesitic volcanoes have been measured. Blattner and Williams (1991) also suggested that the Largs anomaly developed when terrestrial volcanic rocks interacted with high-latitude meteoric water in hydrothermal systems driven by the original volcanic heat sources. Contact metamorphism, ranging from low-pressure homblende- to pyroxenehornfels facies, was subsequently superimposed on rocks already depleted in ${ }^{18} \mathrm{O}$.

The eclogites in the present study are not as depleted in ${ }^{18} \mathrm{O}$ as the Qinglongshan eclogite. Nevertheless, the one negative $\delta^{18} \mathrm{O}$ value along with the low O-isotope compositional range of garnet (Table 2) suggest that the hydrothermal scenario postulated for the Qinglongshan eclogite by Yui et al. (1995) is equally applicable to eclogites in the present study though details, including reaction temperatures and water/rock ratios, may differ. Although the postulation of seawater-oceanic crust interaction (Gregory and Taylor, 1986; MacGregor and Manton, 1986; Ongley et al., 1987) cannot be excluded as a possible explanation for the low but positive $\delta^{18} \mathrm{O}$ values of garnet in most of the eclogite samples in this study, Jahn et al. (1995) concluded that, based on Sr- and Nd-isotope data, none of the eclogites in the Dabie and Sulu UHP terrains bear the isotopic characteristics of the oceanic crust (i.e. mid-ocean ridge basalt, MORB). The large range in $\mathrm{O}$-isotope composition of eclogite garnet in the present study has therefore most probably resulted from pre-subduction hydrothermal interactions between meteoric water and precursor basaltic rocks of non-MORB origin. Since garnet is one of the main constituents in eclogite and has a very slow O-diffusion rate (Fortier and Giletti, 1989) plus the fact that the isotopic fractionations between minerals is small under high-temperature conditions, the $\mathrm{O}$-isotope compositions of garnet may best approximate (probably lower by $1-2 \%$ o than) the $\delta^{18} \mathrm{O}$ values of the host eclogite during UHP metamorphism.

\subsection{Low- $\delta^{18} O$ retrograde fluids}

As mentioned previously, the isotopic disequilibrium fractionations between minerals and garnet for most eclogite samples shown in Fig. 2 can be best interpreted as having resulted from retrograde hydration reactions because omphacite has undergone retrograde recrystallization and amphibole is a retrograde mineral. (It should be kept in mind that the "omphacite" in the present study is actually a mixture of "symplectite" and "true omphacite". Additionally, it is not certain whether the "true omphacite" exchanged its O-isotope composition with the retrograde fluid. However, if the "true omphacite" did not experience the retrograde isotopic exchange, the observed isotopic disequilibrium between "omphacite" and garnet should then be ascribed to the "symplectite" present. Accordingly, the conclusions derived from the following discussions still stand.) The smaller or even reversed O-isotope fractionations between minerals and garnet, compared with the equilibrium ones, clearly indicate that the O-isotope composition of the retrograde fluid must be low albeit not necessarily homogeneous. It is significant to note that the degree of isotopic disequilibrium between omphacite $^{\# 2}$ /amphibole and garnet shows a distinct correlation with the $\delta^{18} \mathrm{O}$ value of garnet (Fig. 2). In addition, the amount of symplectite in omphacite ${ }^{\# 2}$ does not play an important role in the correlative relation (see Table 1 and Fig. 2). Such a correlation can only be reasonably accounted for by the larger $\delta^{18} \mathrm{O}$ contrast between the retrograde fluids and the eclogites with positive $\delta^{18} \mathrm{O}$ values. Thus, the correlation shown in Fig. 2 strongly suggests that the $\delta{ }^{18} \mathrm{O}$ value of the retrograde fluids should most probably have been lower than zero. This conclusion is consistent with the presence of retrograde amphi- 
boles exhibiting negative $\delta^{18} \mathrm{O}$ values in some Dabie eclogites, as reported by Xie (1993).

The postulation that the O-isotope composition of the retrograde fluids is expected to be low is supported by marble data. The isotopic compositions of calcite, dolomite and silicates from the Dabie marbles are shown in Table 3. The $\delta^{18} \mathrm{O}$ values of silicates are plotted against those of carbonates for each sample in Fig. 3. Under UHP metamorphic conditions, the O-isotope fractionations between calcite/dolomite and silicates should at least be larger than zero (e.g., Matthews et al., 1983a,b; Zheng, 1993a,b). Fig. 3 demonstrates that while dolomite in three out of four samples could be in O-isotope equilibrium with the coexisting silicates, the isotopic

Table 3

Isotope compositions of carbonates and silicates in marbles

\begin{tabular}{|c|c|c|c|}
\hline Sample & Mineral & $\begin{array}{l}\delta^{18} \mathrm{O} \\
\text { (\%o vs. SMOW) }\end{array}$ & $\begin{array}{l}\delta^{13} \mathrm{C} \\
\text { (\%o vs. PDB) }\end{array}$ \\
\hline DB14-C & $\begin{array}{l}\text { calcite } \\
\text { silicates }{ }^{\text {a }}\end{array}$ & $\begin{array}{r}+4.9 \\
+10.6\end{array}$ & +2.2 \\
\hline DB-14-D1 & $\begin{array}{l}\text { calcite } \\
\text { silicates }\end{array}$ & $\begin{array}{l}+8.3 \\
+9.9\end{array}$ & +2.8 \\
\hline DB14-D2 & $\begin{array}{l}\text { calcite } \\
\text { silicates }\end{array}$ & $\begin{array}{r}+7.6 \\
+10.6\end{array}$ & +2.5 \\
\hline DB15-A1 & $\begin{array}{l}\text { calcite } \\
\text { dolomite } \\
\text { silicates }\end{array}$ & $\begin{array}{r}+8.7 \\
+14.7 \\
+16.4\end{array}$ & $\begin{array}{l}+1.0 \\
+0.9\end{array}$ \\
\hline DB15-A2G & $\begin{array}{l}\text { calcite } \\
\text { silicates }\end{array}$ & $\begin{array}{r}+7.0 \\
+16.6\end{array}$ & +1.5 \\
\hline DB15-B & $\begin{array}{l}\text { calcite } \\
\text { dolomite } \\
\text { silicates }\end{array}$ & $\begin{array}{l}+10.3 \\
+18.7 \\
+15.3\end{array}$ & $\begin{array}{l}+2.2 \\
+1.8\end{array}$ \\
\hline DB22-DG & $\begin{array}{l}\text { calcite } \\
\text { dolomite } \\
\text { silicates }\end{array}$ & $\begin{array}{l}+10.3 \\
+14.5 \\
+10.4\end{array}$ & $\begin{array}{l}+4.5 \\
+5.1\end{array}$ \\
\hline DB22-DW & $\begin{array}{l}\text { calcite } \\
\text { dolomite } \\
\text { silicates }\end{array}$ & $\begin{array}{l}+10.4 \\
+15.7 \\
+11.3\end{array}$ & $\begin{array}{l}+4.2 \\
+5.2\end{array}$ \\
\hline DB26-A & $\begin{array}{l}\text { calcite } \\
\text { silicates }\end{array}$ & $\begin{array}{l}+12.1 \\
+11.6\end{array}$ & +4.3 \\
\hline DB26-B & $\begin{array}{l}\text { calcite } \\
\text { silicates }\end{array}$ & $\begin{array}{l}+12.3 \\
+14.0\end{array}$ & +4.2 \\
\hline
\end{tabular}

a Silicates consist mainly of mixtures of garnet, clinopyroxene, epidote, quartz, homblende, symplectite and phlogopite.

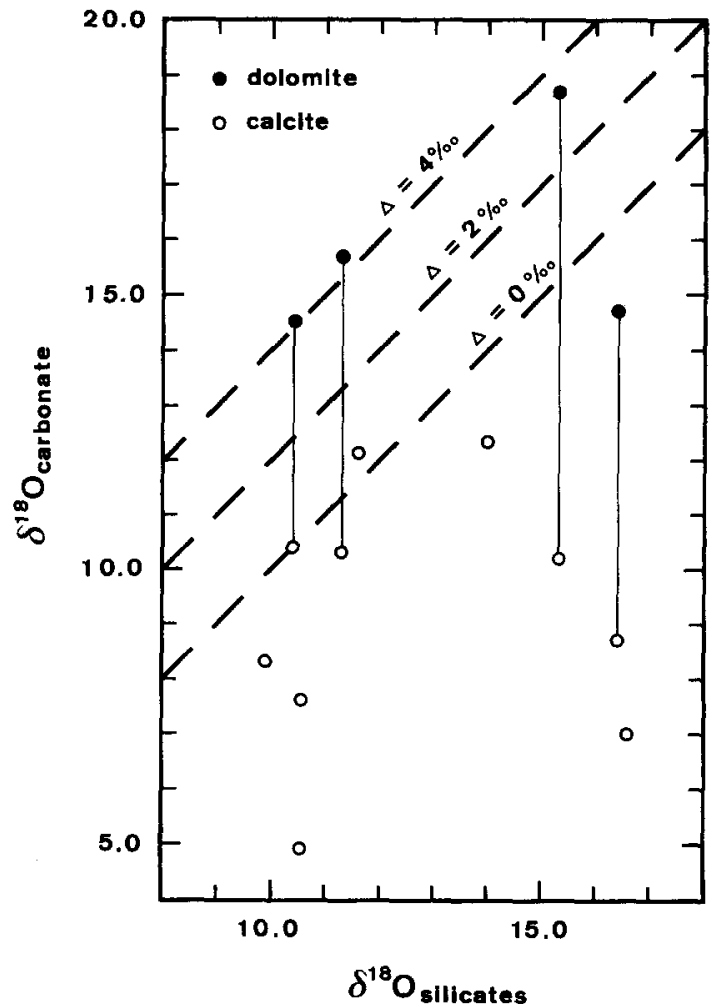

Fig. 3. $\delta^{18} \mathrm{O}$ (carbonates) vs. $\delta^{18} \mathrm{O}$ (silicates) for marble samples. Calcites in most marble samples are not in isotopic equilibrium with the coexisting silicates or dolomites. Tie-lines connect coexisting dolomite and calcite.

fractionation between calcite and silicates is reversed in most samples. The O-isotope fractionation between dolomite and calcite is also too large to be in isotopic equilibrium under UHP metamorphic conditions (Northrop and Clayton, 1966; Sheppard and Schwarcz, 1970). These results are consistent with the notion that calcite is one of the minerals most easily susceptible to retrograde isotopic exchange (e.g., Clayton et al., 1968). The $\delta^{18} \mathrm{O}$ values of calcite show a large range, i.e. from +4.9 to $+12.3 \%$ (Table 3 ), reflecting different degrees of water-rock interactions. The $\delta^{18} \mathrm{O}$ value of the retrograde fluids should be low enough to account for those calcites with low $\delta{ }^{18} \mathrm{O}$ values. Both carbonates and silicates in the present study are mixtures of peak and retrograde metamorphic phases. Although this may complicate the arguments, it will not change the above conclusion. It was suggested that the 
temperature condition of the retrograde metamorphism of these marbles was $475-550^{\circ} \mathrm{C}$ (Wang and Liou, 1993). Accordingly, the lowest O-isotope composition of the retrograde fluids must be lower than +2.8 to $+3.7 \%$ (O'Neil et al., 1969). It should be noted that $\mathrm{C}$-isotope compositions of the coexisting calcite and dolomite are comparable (Table 3). This may imply that the retrograde fluids were either water dominated or had carbon isotope ratios in equilibrium with those of the marble.

The low or even negative $\delta^{18} \mathrm{O}$ value of the retrograde fluids would intrinsically imply a meteoric water origin. The reported $P-T$ conditions for the retrograde metamorphism of eclogites in the Dabie and Sulu UHP terrains cover a wide range, $P=6$ to $>9$ kbar and $T=470^{\circ}$ to $>680^{\circ} \mathrm{C}$ (Wang et al., 1990, 1992; Enami et al., 1993; Cong et al., 1995; Zhang et al., 1995). The inferred retrograde meteoric water-rock interactions should have then occurred at depths of $\sim 15-20 \mathrm{~km}$ during the exhumation of the Dabie and Sulu UHP terrains. The crust at these depths should have been deformed under ductile or at least under brittle-ductile transition regime, as was demonstrated by the structural studies on UHP rocks in the Dabie terrain (Hacker et al., 1995). It is well known that the thermal convection of surface waters is common in the brittle (i.e. upper) crust (e.g., Fyfe et al., 1978). However, the depth limit of such a convection should be located at the brittle-ductile rheological transition zone (Nesbitt, 1988; Nesbitt and Muehlenbachs, 1989). Because there are mechanical difficulties associated with convecting fluids from a high-level source at hydrostatic pressures downward into ductile shear zones containing fluids at lithostatic pressures (e.g., Wood and Walther, 1986), "seismic pumping”, proposed by Sibson et al. (1975), may be one viable mechanism accounting for the deep penetration of meteoric waters into the ductile shear zones (McCaig, 1988). Recent studies have also shown numerous examples of surface waters being able to penetrate downward into ductile shear zones of the middle crust at depths of $10-15 \mathrm{~km}$ during the uplift of metamorphic terrains (Kerrich, 1988; McCaig et al., 1990; Fricke et al., 1992). It is noted that the estimated depths $(15-20 \mathrm{~km})$ at which the amphibolitefacies overprint took place in the present study are a little deeper than those documented in the literature
$(10-15 \mathrm{~km})$. Either the pressure conditions of the amphibolite-facies overprint in the Dabie and Sulu terrains were overestimated, or the surface waters could indeed penetrate to such depths due to the differences in thermal gradient, lithology, strain rate, etc., among terrains.

Alternatively, the retrograde fluids with low or even negative $\delta^{18} \mathrm{O}$ values could have come from the country rocks with low O-isotope compositions. Fluids of any origin with variable $\delta^{18} \mathrm{O}$ values may have first infiltrated into and equilibrated with the country rocks with low $\delta^{18} \mathrm{O}$ values. Such evolved fluids then reacted with the eclogites and were able to form low $-\delta^{18} \mathrm{O}$ retrograde phases in eclogites as observed in the present study. Another possibility is that during unloading some dehydration reactions, such as biotite and K-feldspar replacing phengite and garnet, may have occurred spontaneously in the pelitic rocks and the resulting fluid may have then infiltrated into the nearby/enclosed eclogites, forming partially/completely amphibolitized eclogites. This postulation was employed by Heinrich (1982) to explain the contrasting metamorphic conditions recorded by high-pressure mafic eclogite and adjacent predominantly lower-pressure pelite assemblages in the southern Adula nappe, Central Alps. A similar facies contrast between eclogites and nearby (para)gneisses in the Dabie and Sulu terrains was reported by Wang and Liou (1991) and Okay (1993). Retrograde textures, i.e. phengite replaced by biotite and feldspars, are also not uncommon in the (para)gneisses (Okay, 1993). Most importantly, the O-isotope compositions of the (para)gneisses in the Dabie-Sulu area, like those of eclogites, cover a wide range (Baker et al., 1994; Yui et al., 1994). Some of them are even lower than zero (Baker et al., 1994). The possibility that the fluids responsible for eclogite retrograde hydration reactions have actually equilibrated with or have been derived from dehydration reactions in the nearby low- $\delta{ }^{18} \mathrm{O}$ country rocks, therefore, cannot be excluded.

The O-isotope compositions of some representative (para)gneiss samples in the present study range from +1.7 to $+12.8 \%$ o (Table 4 ). The $\delta^{18} \mathrm{O}$ values of quartz and micas in these (para)gneisses also cover a wide range, i.e. from +2.0 to $+14.1 \% o$ and from -2.5 to $+11.4 \%$, respectively (Table 4 ). The $\mathrm{O}$-isotope fractionations between coexisting quartz 
Table 4

Isotope composition of minerals and rocks for the (para)gneiss samples

\begin{tabular}{|c|c|c|c|c|}
\hline \multirow[t]{2}{*}{ Sample } & \multicolumn{4}{|c|}{$\delta^{18} \mathrm{O}(\% \circ$ vs. SMOW) } \\
\hline & whole rock & quartz & phengite & biotite \\
\hline DB14-E & +12.8 & +14.1 & +11.4 & \\
\hline DB21-A & +1.7 & +2.0 & & -2.5 \\
\hline DB24-A & +7.9 & +9.3 & & +4.3 \\
\hline DB25-A & +8.3 & +9.8 & & +5.5 \\
\hline SD03-B 1 & +7.5 & +8.3 & +6.2 & \\
\hline SD08-A & +6.1 & & & \\
\hline
\end{tabular}

and micas would yield temperature estimates in the range of $450-670^{\circ} \mathrm{C}$ (Javoy, 1977; Zheng, 1993a,b). These results are consistent with their amphibolitefacies mineral assemblages. According to the fractionation relations postulated by Javoy (1977), Richter and Hoernes (1988), Zheng (1993a,b), and Hoffbauer et al. (1994), fluids in equilibrium with or derived from the dehydration reactions in the (para)gneiss samples DB21-A and DB24-A would have $\delta^{18} \mathrm{O}$ values low enough to account for the observed $\mathrm{O}$-isotope compositions of retrograde omphacites in the enclosed eclogite samples DB21-D and DB24-B, respectively. The causes of such low $\delta^{18} \mathrm{O}$ values of these (para)gneisses, however, are not yet clear. The O-isotope compositions of these (para)gneisses could have either been inherited from their non-metamorphic precursors or could have resulted from retrograde meteoric water-rock interactions. Although the former possibility is more likely to be the case, detailed studies on gneissic rocks are needed to shed more light on this issue. It should be noted that except for these two samples, the $\delta^{18} \mathrm{O}$ values of the remaining four (para)gneiss samples are not low enough to account for the observed isotopic fractionations between minerals and garnet in enclosed eclogites. In such cases, the infiltration of fluids from other low- $\delta^{18} \mathrm{O}$ country rocks, such as sample DB21-A, is needed.

On the basis of the available data, it is difficult to differentiate which of the scenarios discussed above is the best to account for the inferred low- $\delta \delta^{18} \mathrm{O}$ retrograde fluids in the Dabie and Sulu UHP terrains. However, one should note that these scenarios are not necessarily mutually exclusive.

\section{Conclusions}

The O-isotope compositions of minerals in eclogites from the Dabie and Sulu terrains cover a wide range, from about -4 to about $+6 \%$, in the present study. Although retrograde reactions are very common, the $\delta^{18} \mathrm{O}$ values of garnet are considered to best approximate the $\mathrm{O}$-isotope variations among eclogites during UHP metamorphism and to have largely been inherited from pre-subduction basaltic precursors. The large $\delta^{18} \mathrm{O}$ range is also thought to have mainly resulted from heterogeneous meteoric water-rock reactions, under different temperature conditions with variable water/rock ratios before UHP metamorphism.

The $\mathrm{O}$-isotope fractionations between omphacite/phengite/amphibole and garnet are not in isotopic equilibrium for most eclogite samples. This is mainly due to retrograde hydration reactions, which caused the low $\delta^{18} \mathrm{O}$ values of the retrograde phases. The fluids responsible for these hydration reactions were probably originated from infiltrated meteoric waters or from fluids which either had equilibrated with low- $\delta^{18} \mathrm{O}$ (para)gneisses or had been derived from dehydration reactions during decompression of the low- $\delta{ }^{18} \mathrm{O}$ country rocks.

\section{Acknowledgements}

The authors would like to thank J.G. Liou, B. Cong and L.S. Teng for initiating this research, and J.G. Liou, Y.N. Shieh and R. Zhang for helpful discussions. Mineral separates for sample SL-26-1 were provided by J.G. Liou. Deep appreciation goes to Z. Sharp and P. Philippot for their critical comments, which greatly improved the discussions in this paper. This is the Institute of Earth Sciences Contribution No. IESEP97-001.

\section{References}

Agrinier, P., Javoy, M., Smith, D.C. and Pineau, F., 1985. Carbon and oxygen isotopes in eclogites, amphibolites, veins and marbles from the Western Gneiss Region, Norway. Chem. Geol. (Isot. Geosci. Sect.), 52: 145-162. 
Al-Aasm, I.S., Taylor, B.E. and South, B., 1990. Stable isotope analysis of multiple carbonate samples using selective acid extraction. Chem. Geol. (Isot. Geosci. Sect.), 80: 119-125.

Ames, L., Tilton, G.R. and Zhou, G., 1993. Timing of collision of the Sino-Korean and Yangtze cratons: $\mathrm{U}-\mathrm{Pb}$ zircon dating of coesite-bearing eclogites. Geology, 21: 339-342.

Baker, J., Matthews, A., Mattey, D., Xue, F. and Rowley, D.B., 1994. Fluid infiltration during ultra-high pressure metamorphism, Dabie Shan, China. Stanford Workshop on UHP Metamorphism and Tectonics, Abstr. Vol., p.75.

Blattner, P. and Williams, J.G., 1991. The Largs high-latitude oxygen isotope anomaly (New Zealand) and climatic controls of oxygen isotopes in magma. Earth Planet. Sci. Lett., 103: $270-284$

Chen, J., Shieh, Y.N. and Sun, X., 1995. A preliminary study of oxygen isotope geochemistry of eclogites from Dabie ultra-high pressure metamorphic terrane. Chin. Sci. Bull., 40: 120-122.

Chen, W., Harrison, T.M.. Heizler, M.T., Liu, R., Ma, B. and Li, J., 1992. The cooling history of melange zone in north Jiangsu-south Shandong region: Evidence from multiple diffusion domain ${ }^{40} \mathrm{Ar}-{ }^{39} \mathrm{Ar}$ thermal geochronology. Acta Pet. Sin., 8: 1-17.

Chopin, C., 1984. Coesite and pure pyrope in high-grade blueschists of the Western Alps: a first record and some consequences. Contrib. Mineral. Petrol., 86: 107-118.

Clayton, R.N. and Mayeda, T.K., 1963. The use of bromine pentafluoride in the extraction of oxygen from oxides and silicates for isotopic analysis. Geochim. Cosmochim. Acta, 27: $43-52$.

Clayton, R.N., Muffler, L.J.P. and White, D.E., 1968. Oxygen isotope study of calcite and silicates of the River Ranch No. 1 well, Salton Sea Geothermal Field, California. Am. J. Sci., 266: 968-979.

Cong, B., Zhai, M., Carswell, D.A., Wilson, R.N., Wang, Q., Zhao, Z. and Windley, B.F., 1995. Petrogenesis of ultrahighpressure rocks and their country rocks at Shuanghe in Dabieshan, central China. Eur. J. Mineral., 7: 119-138.

Desmons, J. and O'Neil, J.R., 1978. Oxygen and hydrogen isotope compositions of eclogites and associated rocks from the Eastern Sesia Zone (Western Alps, Italy). Contrib. Mineral. Petrol., 67: 79-85.

Enami, M., Zang, Q. and Yin, Y., 1993. High pressure eclogites in northern Jiangsu-southern Shandong province, eastern China. J. Metam. Geol., 11: 589-604.

Fortier, S.M. and Giletti, B.J., 1989. An empirical model for predicting diffusion cosfficients in silicate minerals. Science, 245: 1481-1484.

Fricke, H.C., Wickham, S.M. and O'Neil, J.R., 1992. Oxygen and hydrogen isotope evidence for meteoric water infiltration during mylonitization and uplift in the Ruby Mountains-East Humboldt Range core complex, Nevada. Contrib. Mineral. Petrol., 111: 203-221.

Fyfe, W.S., Price, N.J. and. Thompson, A.B., 1978. Fluids in the Earth's Crust. Amsterdam, Elsevier, 383 pp.

Garlick, G.D., MacGregor, I.D. and Vogel, D.E., 1971. Oxygen isotope ratios in eclogites from kimberlites. Science, 172: 1025-1027.
Gregory, R.T. and Criss, R.E., 1986. Isotopic exchange in open and closed systems. In: J.W. Valley, H.P. Taylor, Jr. and J.R. O'Neil (Editors), Stable Isotopes in High Temperature Geological Processes. Mineral. Soc. Am., Rev. Mineral., 16: 91-127.

Gregory, R.T. and Taylor, Jr., H.P., 1986. Non-equilibrium, metasomatic ${ }^{18} \mathrm{O} /{ }^{16} \mathrm{O}$ effects in upper mantle mineral assemblages. Contrib. Mineral. Petrol., 93: 124-135.

Hacker, B.R. and Wang, Q., 1995. Ar/Ar geochronology of ultrahigh-pressure metamorphism in central China. Tectonics, 14: 994-1006.

Hacker, B.R., Ratschbacher, L., Webb, L. and Dong S., 1995. What brought them up? Exhumation of the Dabie Shan ultrahigh-pressure rocks. Geology, 23: 743-746.

Heinrich, C.A., 1982. Kyanite-eclogite to amphibolite facies evolution of hydrous mafic and pelitic rocks, Adula nappe, central Alps. Contrib. Mineral. Petrol., 81: 30-38.

Hirajima, T., Ishiwatari, A., Cong, B., Zhang, R., Banno, S. and Nozaka, T., 1990. Coesite from Mengzhong eclogite at Donghai county, northeastern Jiangsu province, China. Mineral Mag., 54: 579-583.

Hoffbauer, R., Hoernes, S. and Fiorentini, E., 1994. Oxygen isotope thermometry based on a refined increment method and its application to granulite-grade rocks from Sri Lanka. Precambrian Res., 66: 199-220.

Jacob, D., Jagoutz, E., Lowry, D., Mattey, D. and Kudrjavtseva, G., 1994. Diamondiferous eclogites from Siberia: Remnants of Archean oceanic crust. Geochim. Cosmochim. Acta, 58: 5197-5207.

Jahn, B.-m., Cornichet, J. and Cong, B., 1995. Crustal evolution of the Qingling-Dabie orogen: Isotopic and geochemical constraints from coesite-bearing eclogites of the Su-Lu and Dabie terranes, China. Chin. Sci. Bull., 40: 116-119.

Jahn, B.-m., Cornichet, J., Cong, B. and Yui, T.F., 1996. Ultra-high $\epsilon$ Nd eclogites from an ultrahigh pressure metamorphic terranes of China. Chem. Geol., 127: 61-79.

Javoy, M., 1977. Stable isotopes and geothermometry. J. Geol. Soc. London, 133: 609-636.

Kerrich, R., 1988. Detachment zones of Cordilleran metamorphic core complexes: thermal, fluid and metasomatic regimes. Geol. Rundsch., 77: 157-182.

Li, S., Xiao, Y., Liou, D., Chen, Y., Ge, N., Zhang, Z., Sun, S., Cong, B., Zhang, R., Hart, S.R. and Wang, S., 1993. Collision of the north China and Yangtze blocks and formation of coesite-bearing eclogites: timing and processes. Chem. Geol., 109: 89-111.

Li, S., Wang, S., Chen, Y., Liu, D., Qiu, J., Zhou, H. and Zhang, Z., 1994. Excess argon in phengite from eclogite: evidence from dating of eclogite minerals by $\mathrm{Sm}-\mathrm{Nd}, \mathrm{Rb}-\mathrm{Sr}$ and ${ }^{40} \mathrm{Ar} /{ }^{39} \mathrm{Ar}$ methods. Chem. Geol. (Isot. Geosci. Sect.), 112: 343-350.

Lin, L.H., Wang, P.L. and Lo. C.H., 1994. ${ }^{40} \mathrm{Ar} /{ }^{39} \mathrm{Ar}$ geochronology and its tectonic implication for $\mathrm{Su}-\mathrm{Lu}$ ultrahigh-pressure metamorphic terrane, eastern China. Stanford Workshop on UHP Metamorphism and Tectonics, Abstr. Vol., p.83.

Liou, J.G. and Zhang, R.Y., 1995. Introduction to the Dabie ultrahigh- $P$ metamorphic terrane: progress and problems. Chin. Sci. Bull., 40: 141-144. 
Liou, J.G., Zhang, R. and Ernst, W.G., 1994. An introduction to ultrahigh-pressure metamorphism. Island Arc, 3: 1-24.

MacGregor, I.D. and Manton, W.I., 1986. Roberts Victor eclogites: Ancient oceanic crust. J. Geophys. Res., 91: 1406314079.

Matthews, A. and Schliestedt, M., 1984. Evolution of the blueschist and greenschist facies rocks of Sifnos, Cyclades, Greece: A stable isotope study of subduction-related metamorphism. Contrib. Mineral. Petrol., 88: 150-163.

Matthews, A., Goldsmith, J.R. and Clayton, R.N., 1983a. Oxygen isotope fractionation between zoisite and water. Geochim. Cosmochim. Acta, 47: 631-644.

Matthews, A., Goldsmith, J.R. and Clayton, R.N., 1983b. Oxygen isotope fractionation involving pyroxenes: the calibration of mineral-pair geothermometers. Geochim. Cosmochim. Acta, 47: 645-654.

McCaig, A.M., 1988. Deep fluid circulation in fault zones. Geology, 16: 867-870.

McCaig, A.M., Wickham, S.M. and Taylor, Jr., H.P., 1990. Deep fluid circulation in alpine shear zones, Pyrenees, France: field and oxygen isotope studies. Contrib. Mineral. Petrol., 106: $41-60$.

Muehlenbachs, K., 1986. Alteration of the oceanic crust and the ${ }^{18} \mathrm{O}$ history of seawater. In: J.W. Valley, H.P. Taylor, Jr. and J.R. O'Neil (Editors), Stable Isotopes in High Temperature Geological Processes. Mineral. Soc. Am., Rev. Mineral., 16: 425-444.

Nadeau, S., Philippot, P. and Pineau, F., 1993. Fluid inclusion and mineral isotopic compositions $(\mathrm{H}-\mathrm{C}-\mathrm{O})$ in eclogitic rocks as tracers of local fluid migration during high-pressure metamorphism. Earth Planet. Sci. Lett., 114: 431-448.

Nesbitt, B., 1988. The gold deposit continuum: a genetic model for lode $\mathrm{Au}$ mineralozation in the continental crust. Geology, 16: 1044-1048.

Nesbitt, B. and Muehlenbachs, K., 1989. Origins and movement of fluids during deformation and metamorphism in the Canadian Cordillera. Science, 245: 733-736.

Northrop, D.A. and Clayton, R.N., 1966. Oxygen-isotope fractionations in systems containing dolomite. J. Geol., 74: 174-196.

Okay, A.I., 1993. Petrology of a diamond and coesite-bearing metamorphic terrain: Dabie Shan, China. Eur. J. Mineral., 5: 659-673.

Okay, A.I., Xu, S. and Sengor, A.M.C., 1989. Coesite from the Dabie Shan eclogites, central China. Eur. J. Mineral., 1: 595-598.

O'Neil, J.R., Clayton, R.N. and Mayeda, T.K., 1969. Oxygen isotope fractionation in divalent metal carbonates. J. Chem. Phys., 51: 5547-5558.

Ongley, J.S., Basu, A.R. and Kyser, T.K., 1987. Oxygen isotopes in coexisting garnets, clinopyroxenes and phlogopites of Roberts Victor eclogites: implications for petrogenesis and mantle metasomatism. Earth Planet. Sci. Lett., 83: 80-84.

Richter, R. and Hoernes, S., 1988. The application of the increment method in comparison with experimentally derived and calculated O-isotope fractionations. Chem. Erde, 48: 1-18.

Rumble III, D. and Hoering, T.C., 1994. Analysis of oxygen and sulfur isotope ratios in oxide and sulfide minerals by spot heating with a carbon dioxide laser in a fluorine atmosphere. Acc. Chem. Res., 27: 237-241.

Schliestedt, M. and Matthews, A., 1987. Transformation of blueschist to greenschist facies rocks as a consequence of fluid infiltration, Sifnos (Cyclades), Greece. Contrib. Mineral. Petrol., 97: 237-250.

Schreyer, W., 1988. Experimental studies on metamorphism of crustal rocks under mantle pressures. Mineral. Mag., 51: 1-26.

Sharp, Z.D., 1990. A laser-based microanalytical method for the in situ determination of oxygen isotope ratios of silicates and oxides. Geochim. Cosmochim. Acta, 54: 1353-1357.

Sharp, Z.D., 1992. In situ laser microprobe techniques for stable isotope analysis. Chem. Geol., 101: 3-20.

Sheppard, S.M.F. and Schwarcz, H.P., 1970. Fractionation of carbon and oxygen isotopes and magnesium between coexisting metamorphic calcite and dolomite. Contrib. Mineral. Petrol., 26: 161-198.

Sibson, R.H., Moore, J.M.M. and Rankin, A.H., 1975. Seismic pumping-hydrothermal fluid transport mechanism. J. Geol. Soc. London, 131: 653-659.

Sobolev, N.V. and Shatsky, V.S., 1990. Diamond inclusions in garnets from metamorphic rocks: a new environment for diamond formation. Nature (London), 343: 742-746.

Taylor, Jr., H.P., 1968. The oxygen isotope geochemistry of igneous rocks. Contrib. Mineral. Petrol., 19: 1-71.

Taylor, Jr., H.P. and Coleman, R.G., 1968. $\mathrm{O}^{18} / \mathrm{O}^{16}$ ratios of coexisting minerals in glaucophane-bearing metamorphic rocks. Geol. Soc. Am. Bull., 79: 1727-1756.

Valley, J.W., 1986. Stable isotope geochemistry of metamorphic rocks. In: J.W. Valley, H.P. Taylor, Jr. and J.R. O'Neil (Editors), Stable Isotopes in High Temperature Geological Processes. Mineral. Soc. Am., Rev. Mineral., 16: 445-489.

Vogel, D.E. and Garlick, G.D., 1970. Oxygen isotope ratios in metamorphic eclogites. Contrib. Mineral. Petrol., 28: 183-191.

Wang, X. and Liou, J.G., 1991. Regional ultrahigh-pressure coesite-bearing eclogitic terrane in central China: Evidence from country rocks, gneiss, marble and metapelite. Geology, 19: 933-936

Wang, X. and Liou, J.G., 1993. Ultrahigh-pressure metamorphism of carbonate rocks in the Dabie Mountains, central China. J. Metam. Geol., 11: 578-588.

Wang, X., Liou, J.G. and Mao, H.K., 1989. Coesite-bearing eclogites from the Dabie Mountains in central China. Geology, 17: 1085-1088.

Wang, X., Jing, Y., Liou, J.G., Pan, G., Liang, W., Xia, M. and Maruyama, S., 1990. Field occurrences and petrology of eclogites from the Dabie Mountains, Anhui, central China. Lithos, 25: 119-131.

Wang, X., Liou, J.G. and Maruyama, S., 1992. Coesite-bearing eclogites from the Dabie Mountains, Central China: Petrology and $P-T$ path. J. Geol., 100: 231-250.

Wood, B.J. and Walther, J.V., 1986. Fluid flow during metamorphism and its implication for fluid-rock ratios. In: J.V. Walther and B.J. Wood (Editors), Fluid-Rock Interactions During Metamorphism. Springer, Berlin, pp. 89-108. 
Xie, D., 1993. Oxygen isotope compositions of several metamorphic belts in SE China. Acta Petrol. Sin., 9: 125-134 (in Chinese)

Xu, S., Okay, A.I., Ji, S., Sengor, A.M.C., Su, W., Liu, Y. and Jiang, L., 1992. Diamond from the Dabie Shan metamorphic rocks and its implication for tectonic setting. Science, 256: 80-82.

Yang, J. and Smith, D.C., 1989. Evidence for a former sanidinecoesite-eclogite at Lanshantou, east China, and the recognition of the Chinese "Su-Lu coesite-eclogite province'. In: Third International Eclogite Conference. Blackwell, Oxford.

Yui, T.F., Rumble III, D., and Lo, C.H., 1994. Stable-isotope characteristics of the ultra-high pressure (UHP) metamorphic rocks of China. Stanford Workshop on UHP Metamorphism and Tectonics, Abstr. Vol., p.76.

Yui, T.F., Rumble III, D., and Lo, C.H., 1995. Unusually low $\delta^{18} \mathrm{O}$ ultra-high-pressure metamorphic rocks from the Sulu Terrain, eastern China. Geochim. Cosmochim. Acta, 59: 2859-2864.

Zhang, R., Hirajima, T., Banno, S., Cong, B. and Liou, J.G., 1995. Petrology of ultrahigh-pressure rocks from the southern Sulu region, eastern China. J. Metam. Geol., 13: 659-675.

Zheng, Y.F., 1993a. Calculation of oxygen isotope fractionation in anhydrous silicate minerals. Geochim. Cosmochim. Acta, 57: 1079-1091.

Zheng, Y.F., 1993b. Calculation of oxygen isotope fractionation in hydroxyl-bearing silicates. Earth Planet. Sci. Lett., 120: 247-263.

Zheng, Y.F., Fu, B., Gong, B. and Li, S., 1995. Unusually light oxygen in eclogite from Qinglongshan in the Su-Lu terrane. Chin. Sci. Bull., 40: 129-130. 